Annales de Parasitologie (Paris), 1976, t. 51, $\mathrm{n}^{\circ} 6$, pp. 647 à 652

\title{
Survival of hydatid cysts after puncturing
}

\author{
by E. A. COLTORTI and V. M. VARELA-DIAZ \\ Pan American Zoonoses Center, Pan American Health Organization, \\ World Health Organization, Casilla 3092 - Correo Central, \\ Buenos Aires, Argentina
}

\section{Summary}

The release of antigens from hydatid cysts, essential for the induction of a detectable host antibody response, is considered to depend on alterations in the physical integrity of the cyst germinal membrane. This explanation, however, does not account for the detection of serologic responses in persons harbouring hyaline cysts unless it were possible for membrane microfissures to arise and provide an antigenic stimulus without adversely affecting cyst viability.

The results of the present study have demonstrated that hydatid cysts are able to survive when experimentally punctured in vitro or in vivo. These findings on the capacity of hyaline cysts to repair or recuperate from a microfissure are consistent with the detection of antibody responses in persons harbouring hyaline hydatid cysts with apparently intact membranes and with the hypothesis of an association between integrity of cyst membranes and degree of host immunological responses.

\section{Résumé.}

\section{Survie du kyste hydatique après fissuration.}

La libération d'antigènes nécessaires à l'induction d'un taux d'anticorps sérologiquement décelable chez les porteurs de kystes hydatiques résulterait classiquement d'altérations anatomiques de la membrane germinale. Cette explication semble en défaut quand des réactions sérologiques sont détectées chez des sujets qui hébergent des kystes hyalins, sauf si l'on suppose que des microfissures peuvent survenir dans la membrane et entraîner le stimulus antigénique indispensable, sans pour autant affecter la viabilité de l'hydatide.

Les résultats du présent travail démontrent que les hydatides peuvent survivre à une ponction expérimentale réalisée in vivo et in vitro. La membrane des larves est donc capable de se reconstituer ou de se réparer après une microfissuration. Cette observation est parfaitement compatible avec la détection d'anticorps chez les sujets hébergeant des kystes hyda- 
tiques hyalins aux membranes apparemment intactes, ainsi qu'avec la notion d'un rapport entre l'intégrité de la membrane de la larve et l'intensité de la réponse immunologique de l'hôte.

\section{Introduction}

A number of investigators (Lemaire, 1926 ; Rosas Costa, 1947 ; Faiguenbaum and Miranda, 1949 ; Capron et al., 1970 ; Yarzábal et al., 1974) have reported the existence of an association between the physical integrity of the hydatid cyst membrane, the release of hydatid fluid antigens and the ensuing host serological response. Thus, when the antigenic stimulation induced by the hydatid fluid antigens is intense, as in cases of recently ruptured cysts, a serologic response is detectable in a majority of patients (Capron et al., 1970 ; Yarzábal et al., 1974). In contrast, when this stimulation is reduced or absent, as in the case of a large proportion of patients with hyaline or calcified cysts, there is little or no antibody response detectable (Abou Daoud, 1965 ; Williams et al., 1971).

Many persons harbouring a hyaline hydatid cyst, however, do show a detectable antibody response to hydatid fluid antigens (Capron et al., 1970 ; Yarzábal et al., 1974 ; López-Lemes and Varela-Díaz, 1975). These results are difficult to interpret in terms of the postulate that the physical state of the cyst membranes influences the degree of antigenic stimulation of the host immune system, unless it were assumed that microfissures may occur in some hyaline cysts, allowing the release of hydatid fluid antigens.

There is no evidence, however, that a hydatid cyst is able to survive in a hyaline state after a microfissure occurs on its germinal membrane tegument. Furthermore, nothing is known of the capacity of the hydatid cyst germinal membrane tegument to regenerate or to repair such a fissure.

Thus, the present study was designed to determine if hydatid cysts are able to remain in a viable, turgid, hyaline state after puncturing with a needle and removing a sample of hydatid cyst fluid.

\section{Materials and methods}

\section{Source of eysts.}

Healthy, hyaline cysts of $15-20 \mathrm{~mm}$ in diameter, found free in the peritoneal cavity were obtained from mice infected 12-14 months previously with 1000 viable sheep protoscoleces.

\section{In vitro studies.}

A total of 120 cysts were distributed in a series of $40 \times 120 \mathrm{~mm}$ glass tubes, each containing $25 \mathrm{ml}$ of 199 medium and five hydatid cysts. The tubes were then 
divided into seven groups as shown in Table 1 . All cysts in each respective group were pierced with different gauge sterile needles ( $27 \mathrm{G}, 25 \mathrm{G}, 23 \mathrm{G}, 22 \mathrm{G}, 20 \mathrm{G}$ or 18 Gauge) and a volume of 50-100 $\mu \mathrm{l}$ was aspirated from each cyst. The seventh group of cysts was left as the nonpunctured cyst control.

All cysts were maintained for 72 hours at $37^{\circ} \mathrm{C}$ in the 199 medium, after which time each cyst was implanted into the peritoneal cavity of a gerbil. A month later, recipient gerbils were sacrificed and the viability of the transplanted cysts was assessed on the basis of their macroscopic appearance (Coltorti and Varela-Díaz, 1975a). Accordingly, cysts pierced in vitro were classified as viable if they retained, after implantation into gerbils, their original hyaline appearance, turgor, shape and elasticity and as dead if they showed a loss in fluid contents, a flattened appearance and a torn germinal membrane.

\section{In vivo studies.}

To determine if the in vitro observations were also applicable to the in vivo situation, a second experiment was then carried out. A group of 30 mouse hydatid cysts was implanted into the peritoneal cavity of gerbils as described earlier (Varela-Díaz et al., 1974). A week later, twenty of these animals were anaesthetized and the transplanted cyst was detected in the peritoneal cavity by palpation through the skin. A 25 -gauge sterile needle was then inserted, through the gerbil skin and abdominal wall, into the hydatid cyst and a volume of $50-100 \mu .1$ of hydatid fluid was collected by aspiration to ensure that the cyst had been pierced. The other ten gerbils bearing an implanted mouse hydatid cyst remained as the non-punctured cyst controls. All recipient animals were sacrified 30 days later and the viability of the transplanted cysts was also assessed on the basis of macroscopic appearance (Coltorti and Varela-Díaz, $1975 a)$.

\section{Results}

\section{In vitro studies.}

The observed effect on cyst viability of piercing hydatid cysts in vitro with different gauge needles is shown in Table $I$. The results clearly indicate that hydatid cysts are able to survive when pierced with fine gauge $(22-27 \mathrm{G})$ needles. Their capacity to survive a fissure was seen to depend on the gauge of the needle since cyst survival was reduced when $20 \mathrm{G}$ needles were employed and no cysts survived puncture with an $18 \mathrm{G}$ needle.

\section{In vivo studies.}

Eighteen out of the twenty implanted hydatid cysts ( 90 per cent) survived in the peritoneal cavity of gerbils even though they had been pierced, in vivo, 30 days previously with a $25 \mathrm{G}$ needle. The ten hydatid cysts which constituted the transplanted, 
non-punctured control group were also found to be in a viable state at the end of the experiment.

TABLE I. - Results obtained after implantation of hydatid cysts into the peritoneal cavity of gerbils for 30 days following puncturing with different gauge needles while maintained in vitro.

\begin{tabular}{|c|c|c|c|c|}
\hline Needle caliber & $\begin{array}{l}\text { Number of cysts } \\
\text { per group }\end{array}$ & $\begin{array}{c}\text { Number of viable } \\
\text { cysts after } \\
\text { implantation }\end{array}$ & $\begin{array}{l}\text { Number of dead } \\
\text { cysts after } \\
\text { implantation }\end{array}$ & $\begin{array}{l}\text { Per cent viable } \\
\text { cysts after } \\
\text { implantation }\end{array}$ \\
\hline $27 \mathrm{G} \quad \ldots \ldots \ldots \ldots \ldots$ & 60 & 57 & 3 & 95 \\
\hline $25 \mathrm{G} \ldots \ldots \ldots \ldots \ldots$ & 10 & 9 & 1 & 90 \\
\hline $23 \mathrm{G} \quad \ldots \ldots \ldots \ldots$ & 10 & 8 & 2 & 80 \\
\hline $22 \mathrm{G} \ldots \ldots \ldots \ldots \ldots$ & 10 & 9 & 1 & 90 \\
\hline $20 \mathrm{G} \quad \ldots \ldots \ldots \ldots \ldots$ & 10 & 4 & 6 & 40 \\
\hline $28 \mathrm{G} \quad \ldots \ldots \ldots \ldots \ldots$ & 10 & 0 & 10 & 0 \\
\hline without piercing $\ldots$. & 10 & 10 & 0 & 100 \\
\hline
\end{tabular}

\section{Discussion}

The survival of hydatid cysts after puncture in vitro and in vivo, observed in the present studies, suggest a capacity of the germinal membrane tegument of this metacestode to repair or recuperate from a microfissure. The mechanism by which this occurs, however, remains to be determined.

It has been postulated (Coltorti and Varela-Díaz, 1974) that the germinal membrane serves as a barrier to the entrance of macromolecules into the hydatid fluid and subsequent work (Lascano et al., 1975) suggested that the tegument of the hydatid cyst germinal membrane constituted the only physical obstacle to their penetration. These considerations seem equally adequate to account for the release of macromolecules from the hydatid fluid in cysts with an unaltered membrane.

It was recently demonstrated (Coltorti and Varela-Díaz, $1975 \mathrm{~b}$ ) that the entrance of macromolecules into hyaline cysts is irregular and on this basis it was proposed that the passage of macromolecules from the laminated layer to the hydatid fluid could result from the occasional formation of microfissures in the germinal membrane tegument. The present findings on the survival of pierced hydatid cysts are consistent with this hypothesis, since the formation of occasional microfissures has thus been shown to be compatible with the hyaline state of cysts.

Previous work (Varela-Díaz et al., 1974) suggested that the prolonged survival of hyaline hydatid cysts in an immunocompetent host is the result of a low level of antigenic stimulation by the cyst, which is insufficient to induce a host response adverse to its survival. The observation (Abou Daoud, 1965 ; Williams et al., 1971; Yarzábal et al., 1974) that sera from persons harbouring hyaline cysts may reveal little or no antibody activity to hydatid cyst fluid by a variety of immunodiagnostic tests. 
(Varela-Díaz et al., $1975 a, b$ ) seems also in agreement with the low immunogenicity of this category of cysts.

Hydatid cysts are classified as being in the hyaline state if the fluid within is transparent and clear and its parasite membranes are found to be unaltered by macroscopic examination (Yarzábal et al., 1974). The absence of reactivity in sera from patients harbouring such cysts supports the hypothesis (Lemaire, 1926; Rosas Costa, 1947 ; Faiguenbaum and Miranda, 1949 ; Capron et al., 1970 ; Yarzábal et al., 1974) that detection of serologic activity is dependent on cyst membrane alterations, which allow antigen release. This explanation, however, does not seem adequate to explain the serologic activity observed in some persons harbouring hydatid cysts which correspond to this classification (Capron et al., 1970 ; Yarzábal et al., 1974 ; López-Lemes and Varela-Díaz, 1975).

The present findings on the survival of hydatid cysts in vivo and in vitro after piercing with a fine needle, however, suggest that minute fissures which go undetected by macroscopic examination could occur naturally in hyaline cysts. This would result in the leakage of hydatid fluid and the subsequent induction of a host immunological response. This explanation seems adequate to account for the antibody response observed in persons bearing hyaline hydatid cysts with apparently intact membranes.

\section{Bibliography}

Abou Daoud (K. T.), 1965. - Comparison of the indirect hemagglutination, intradermal and complement fixation tests in hydatid disease, and observations on the fertility of hydatid cysts in humans. Am. J. trop. Med. Hyg., 14, 760-764.

Capron (A.), Yarzabal (L.), Vernes (A.) and Fruit (G.), 1970. — Le diagnostic immunologique de l'echinococcose humaine. (Bilan personnel à propos de 400 observations). Path. Biol., 18, 357-365.

Coltorti (E. A.) and Varela-Diaz (V. M.), 1974. - Echinococcus granulosus: penetration of macromolecules and their localization on the parasite membranes of cysts. Exp. Parasitol., 35, 225-231.

Coltorti (E. A.) and VArela-Diaz (V.M.), 1975 a. - Survival and viability criteria of hydatid cysts maintained in vitro. J. Parasitol., 61, 974-976.

Coltorti (E. A.) and Varela-Diaz (V. M.), 1975 b. - Penetration of host IgG molecules into hydatid cysts. Z. Parasitenk., 48, 47-51.

Faiguenbaum (J.) and Miranda (G.), 1949. - Revisión y actualizacion de la reaccion de Casoni para el diagnóstico de la hidatidosis. Bol. Inf. Parasit. Chilenas, 4, 7-10.

Lascano (E. F.), Coltorti (E. A.) and Varela-Diaz (V. M.), 1975. - Fine structure of the germinal membrane of Echinococcus granulosus cysts. J. Parasitol., 61, 853-860.

Lemaire (G.), 1926. - Recherches sur la perméabilité des kystes hydatiques et sur la nature de poison hydatique. Presse Méd., 2, 1187.

Lopez-Lemes (M. H.) and Varela-Diaz (V. M.), 1975. - Application of the immunoelectrophoresis test for hydatidosis in patients with a presumptive diagnosis of the disease. Trop. Geogr. Med., 27, 301-304. 
Rosas-Costa (G. A.), 1947. - Estado inmunitario entozoósico. Imp. Ferrari Hnos Publ., Buenos Aires, 1116 p.

Varela-Diaz (V. M.), Williams (J. F.), Coltorti (E. A.) and Williams (C. S. F.), 1974. Survival of cysts of Echinococcus granulosus after transplant into homologous and heterologous hosts. J. Parasitol., 60, 608-612.

Varela-Diaz (V. M.), Lopez-Lemes (M. H.), Prezioso (U.), Coltorti (E. A.) and Yarzabal (L. A.), $1975 a$. - Evaluation of four variants of the indirect hemagglutination test for human hydatidosis. Am. J. trop. Med. Hyg., 24, 304-311.

Varela-Diaz (V. M.), Coltorti (E. A.), Prezioso (U.), Lopez-Lemes (M. H.), Guisantes (J. A.) and YARZABAL (L. A.), $1975 b$. - Evaluation of three immunodiagnostic tests for human hydatid disease. Am. J. trop. Med. Hyg., 24, 312-319.

Williams (J.F.), 1972. - An evaluation of the Casoni test in human hydatidosis using an antigen solution of low nitrogen concentration. Trans. Roy. Soc. trop. Med. Hyg., $66,160-164$.

Yarzabal (L. A.), Leiton (J.) and Lopez-Lemes (M. H.), 1974. - The diagnosis of human pulmonary hydatidosis by the immunoelectrophoresis test. Am. J. trop. Med. Hyg., $23,662-666$. 